\title{
Late-onset anterior chamber inflammatory reaction after uneventful cataract surgery: Case report
}

\section{Reacción inflamatoria tardía en la cámara anterior tras facoemulsificación no complicada: reporte de un caso}

\author{
Alejandra Méndez-León ${ }^{1}$, Claudia Corredor-Ortega ${ }^{1 *}$, Roberto González-Salinas², \\ Guadalupe Cervantes-Coste ${ }^{1}$, and Cecilio Velasco-Barona ${ }^{1}$ \\ ${ }^{1}$ Department of Anterior Segment; ${ }^{2}$ Research Department. Asociación para Evitar la Ceguera, Mexico City, Mexico
}

\begin{abstract}
Retained nuclear fragments are a potential complication after cataract surgery and its frequency increases after intraoperative complications such as a posterior capsular tear. When fragments are retained in the anterior chamber, usually there is a postoperative inflammatory reaction during the first days or weeks after surgery. We present the case of a 78-year-old male patient who attended our practice due to sudden onset of red-eye and ocular pain 13 months after uneventful cataract surgery, with no symptoms during this time period. Due to the presence of a retained nuclear fragment in the anterior chamber, surgical removal was performed. After the procedure, all signs and symptoms disappeared. Despite its low frequency, it is important to consider retained nuclear fragments as a possible cause in patients with a late-onset inflammatory reaction after uneventful cataract surgery.
\end{abstract}

Key words: Retained nuclear fragment. Anterior chamber. Late-onset inflammation. Cataract surgery.

\section{Resumen}

La retención de fragmentos nucleares es una complicación probable en la cirugía de catarata y aumenta su incidencia especialmente ante complicaciones transoperatorias tales como la ruptura de la cápsula posterior. Cuando los restos se localizan en la cámara anterior, habitualmente se manifiesta con inflamación postoperatoria en los primeros días o semanas tras el procedimiento. A continuación, se presenta el caso clínico de un paciente de sexo masculino de 78 años que consultó por ojo rojo y dolor súbito 13 meses después de una cirugía de catarata sin complicaciones en dicho ojo, el mismo tiempo que estuvo asintomático. En la valoración se observó un fragmento nuclear en la cámara anterior y se procedió a su remoción quirúrgica. Tras el procedimiento, los signos y síntomas desaparecieron. Los fragmentos nucleares retenidos es una situación poco frecuente pero a considerar como posibilidad de inflamación ocular con inicio tardío posterior a una cirugía de catarata de rutina.

Palabras clave: Fragmento nuclear retenido. Cámara anterior. Inflamación tardía. Cirugía de catarata.

\section{Correspondence:}

${ }^{*}$ Claudia Corredor-Ortega

Vicente García Torres, 46

Date of reception: 19-06-2019

Date of acceptance: 11-03-2020

E-mail: corredorortegaclaudia@gmail.com 2604-1731/@ 2020 Sociedad Mexicana de Oftalmología. Published by Permanyer. This is an open access article under the CC BY-NC-ND license (http://creativecommons.org/licenses/by-nc-nd/4.0/). 


\section{Introduction}

Complications in cataract surgery vary and include the retention of nuclear fragments in the anterior chamber, which in most cases may manifest with early and persistent postoperative inflammation; however, in rare cases, the patient may remain asymptomatic for long periods of time ${ }^{1}$. This is why retained fragments should be considered when there is a late-onset inflammation in the anterior chamber after intraocular surgery. Similarly, it is important to rule out other causes such as underlying uveitis, recent-onset inflammatory eye disease, retinal detachment or infectious endophthalmitis ${ }^{2,3}$.

The purpose of this report is to describe the case of a patient with late-onset inflammation symptoms in the anterior chamber, after 380 days of an uncomplicated phacoemulsification, with an intact posterior capsule. A retained nuclear fragment was found as the cause of inflammation.

\section{Case description}

This is the case of a 78-year-old male who only referred controlled psoriasis. He underwent phacoemulsification with intraocular lens implantation in the capsular bag in the right eye (+18.50 diopters (D) AcrySof $($ IQ) 13 months before. After an uncomplicated surgery and with the posterior capsule intact, he had an uncorrected visual acuity (UCVA) of 20/20 on the Snellen chart without clinical signs or symptoms of intraocular inflammation. The same findings were reported up to the 3-month postoperative visit. He did not attend further follow-up appointments.

Thirteen months after cataract surgery, he returned to the consultation and reported a 1-day history of redness and pain in the operated eye, as well as decreased visual acuity (VA). On examination, UCVA was 20/50 on the Snellen chart, with intraocular pressure (IOP) of 10 $\mathrm{mmHg}$. Biomicroscopic examination revealed mild diffuse corneal stromal edema, with inflammatory cells in the anterior chamber (15-20 per field) and a nuclear fragment retained in the iridocorneal angle at the 7 o'clock meridian (Fig. 1). Fundoscopy under pharmacological pupil dilation showed no alterations. Ultrasound biomicroscopy allowed the measurement of the fragment, which was $1.77 \times 0.70 \mathrm{~mm}$, and the presence of other fragments was excluded, especially in the posterior chamber (Fig. 2). Subsequently, due to the edema, steroidal anti-inflammatory drugs were considered a treatment. As the involvement was mainly stromal, we started topical prednisolone acetate every 2 hours, and

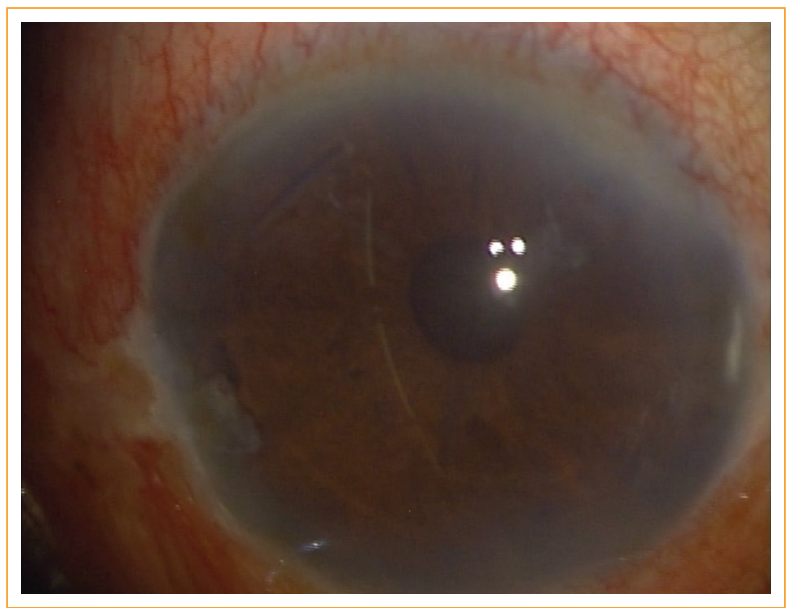

Figure 1. Clinical photograph of the right eye showing a nuclear fragment retained in the iridocorneal angle at the 7 o'clock meridian.

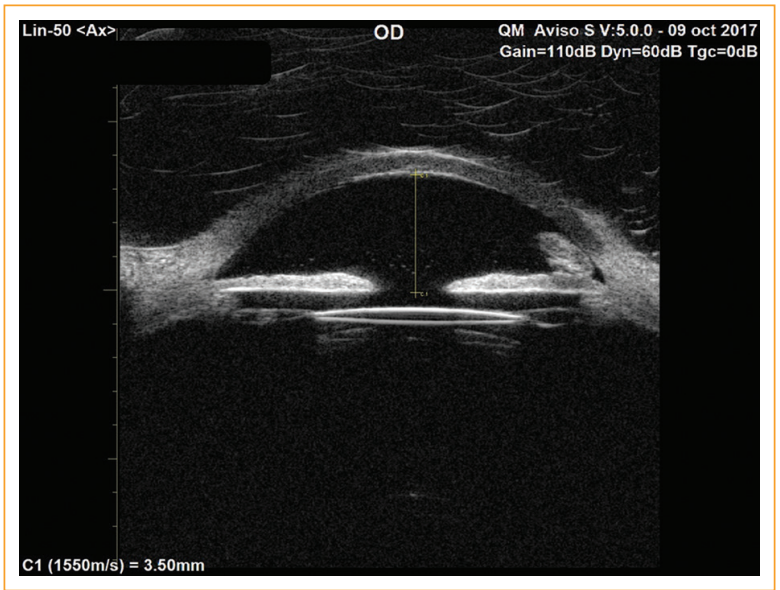

Figure 2. Ultrasound biomicroscopy of the anterior segment of the right eye showing a single nuclear fragment of $0.70 \times 1.77 \mathrm{~mm}$, located at the $7 \mathrm{o}^{\prime}$ clock meridian.

the surgical removal of the fragment was scheduled one week after treatment initiation. Inflammation decreased and, consequently, visualization of the anterior chamber improved prior to surgery.

On the day of the procedure and 1 hour before entering the operating room, a drop of $2 \%$ topical pilocarpine was placed to induce miosis and avoid the migration of the fragment to the posterior chamber. Once in the operating room and after the standardized asepsis and antisepsis measures, the anterior chamber entry was performed by reopening the incisions from the previous cataract surgery, both the paracentesis 


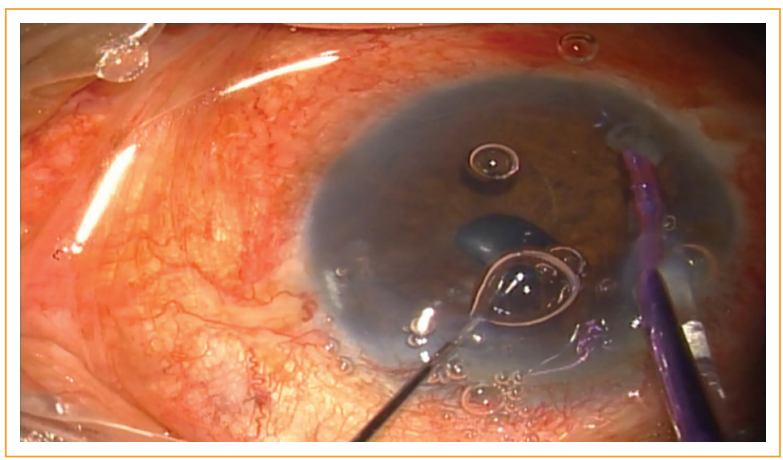

Figure 3. Clinical photograph with pharmacologically induced miosis showing fragment removal with the phaco handpiece.

and the main incision of 1 and $2.2 \mathrm{~mm}$, respectively. Subsequently, a viscoelastic (DisCoVisc $®$ ) was injected into the anterior chamber to protect the corneal endothelium, and the nuclear fragment was removed using both the phacoemulsification handpiece and a Seibel-type chopper; then the procedure concluded after viscoelastic removal and incisions hydration (Fig. 3). In the immediate postoperative period, antibiotic and topical anti-inflammatory treatment was started with moxifloxacin every 4 hours for 1 week and prednisolone acetate every 2 hours, with a tapering schedule every 5 days. After the first postoperative week, UCVA was 20/20 on the Snellen chart, the cornea was clear and there was no anterior chamber inflammation.

\section{Discussion}

Intraocular inflammation secondary to retained lens fragments is frequently observed in the early postoperative period after cataract surgery; however, a late onset presentation has been reported. The only cases reported with a longer evolution compared to our case, are one of 102 and another of 180 months after cataract surgery ${ }^{4,5}$.

Like in the case of our patient, the symptoms and signs reported after fragment retention are decreased VA, cells in the anterior chamber and corneal edema. Most publications report a normal intraocular pressure; however, our patient had an IOP in the lower limits ${ }^{1,2}$. Specifically, VA decrease may be due to corneal edema or macular edema secondary to chronic intraocular inflammation, as reported by Asensio-Sánchez, who evidenced macular edema one month after the procedure ${ }^{1,3}$.

On the other hand, contrary to what was observed in our patient, two cases of retained lens fragments without anterior chamber inflammation have been published. They were diagnosed by ultrasound biomicroscopy, showing a nuclear fragment retained between the iris pigment epithelium and the anterior lens capsule. The only finding by slit-lamp examination was a focal anterior displacement of the iris ${ }^{6}$.

Hui, et. al. published a case series with nuclear fragments retention after cataract surgery without complications in 16 eyes. In this series, preoperative refraction was recorded in 10 patients, 7 of whom were myopic $(-0.76$ to $-14 \mathrm{D})$, as in the case of our patient, whose preoperative refraction was $-4.50 \mathrm{D}$. On the other hand, of the 10 patients in whom axial length was measured by ultrasound, a mean of $24.92 \mathrm{~mm}$ was documented, a value similar to that of this report, of 24.00 $\mathrm{mm}^{2}$. Finally, in this series, $93.75 \%$ (15 eyes) required surgical removal; the exception was a patient whose systemic comorbidities contraindicated surgery, so performing fragmentation with Nd:YAG laser allowed reabsorption of the small fragments through the trabecular meshwork'.

There are few reports in the literature about retained lens fragments in the anterior chamber. This can be explained in part because in most cases, the fragment is located in the vitreous cavity after the posterior capsule rupture with a remnant of the lens. To the best of our knowledge, there are only two case reports of retained lens fragments with an intact capsule that showed symptoms after a period longer than that of our patient, 102 and 180 months, respectively ${ }^{4,5}$.

In summary, we consider that the reason for symptoms appearance one or more years after cataract surgery may be due to the location of the fragment in the area behind the iris; however, when the nuclear fragment migrates into the anterior chamber, an inflammatory response is triggered. We can conclude that, in cases of intraocular inflammation after cataract surgery, one of the differential diagnosis to consider should be retained lens fragments, even months or years after surgery. Also, we conclude that to treat ocular inflammation and avoid its sequelae, it is necessary to perform the surgical removal of any fragment or, as an alternative, use Nd:YAG laser fragmentation.

\section{Funding}

The authors received no funding for this work.

\section{Conflicts of interest}

The authors declare no conflicts of interest. 


\section{Ethical disclosures}

Protection of human and animal subjects. The authors declare that no experiments were performed on humans or animals for this study.

Confidentiality of data. The authors declare that they have followed the protocols of their Institution

on the publication of patient data.

Right to privacy and informed consent. The authors have obtained the written informed consent of the patients or subjects mentioned in the article. The corresponding author is in possession of this document.

\section{References}

1. Asensio-Sánchez VM, Ajamil S, Ramoa-Osorio R, Trujillo-Guzmán L. Edema macular agudo 2 años después de la cirugía de catarata por un fragmento nuclear retenido. Arch Soc Esp Oftalmol. 2014;89(7):272-4.

2. Hui JI, Fishler J, Karp CL, Shuler MF, Gedde SJ. Retained Nuclear Fragments in the Anterior Chamber after Phacoemulsification with an Intact Posterior Capsule. Ophthalmology. 2006;113(11):1949-53.

3. Mokhtarzadeh A, Kaufman SC, Koozekanani DD, Meduri A. Delayed presentation of retained nuclear fragment following phacoemulsification cataract extraction. J Cataract Refract Surg. 2014;40(4):671-4.

4. Pandit RT, Coburn AG. Sudden corneal edema due to retained lens nuclear fragment presenting 8.5 years after cataract surgery. J Cataract Refract Surg. 2011;37(6):1165-7.

5. Kang HM, Park JW, Chung EJ. A retained lens fragment induced anterior uveitis and corneal edema 15 years after cataract surgery. Korean $\mathrm{J}$ Ophthalmol. 2011;25(1):60-2.

6. Oliveira C, Liebmann JM, Dodick JM, Topilow H, Cykiert R, Ritch R. Identification of Retained Nucleus Fragment in the Posterior Chamber Using Ultrasound Biomicroscopy. Am J Ophthalmol. 2006;141(5):964-6. 